\title{
BERKARYA UNTUK BANGSA : SINERGISITAS PENGABDIAN KEPADA MASYARAKAT DAN EDUKASI STRATEGI DIGITAL MARKETING DI SOCIETY 5.0
}

\author{
Abdul Aziz ${ }^{*}$, Muhadi ${ }^{2}$, Eka Assolehah Putri ${ }^{3}$ \\ ${ }^{123}$ Universitas Bina Bangsa (UNIBA) \\ *azizkakang82@gmail.com
}

\begin{abstract}
ABSTRAK
Pengusaha ekonomi kreatif di Desa Ragas Masigit, Kec. Carenang Kab. Serang mengalami permasalahan pengetahuan pemasaran digital pada masa Pandemi Covid-19 menuju society 5.0. Perlu adanya motivasi dan edukasi yang dapat membantu para pelaku usaha ekonomi kreatif khususnya untuk bangkit kembali dari ketidakpastian kondisi saat ini. Tujuan kegiatan ini yaitu untuk meningkatkan sinergisitas pengabdian kepada masyarakat dan menjelaskan mengenai strategi pemasaran digital pada era society 5.0.Jenis penelitian yang digunakan dalam penelitian ini adalah survey dan studi kasus dengan metode deskriptif yaitu dengan ceramah, diskusi dan pendampingan. Materi yang disampaikan padapengabdian masyarakat ini yaitu pola strategi pemasaran digital dalam mengembangkan ekonomi kreatif pada masa pandemi covid 19. Hasil dari kegiatan ini adalah pengetahuan strategi pemasaran digital yang menyeluruh oleh peserta dapat diimplementasikan dan produk yang diminati serta dibutuhkan saat ini yang dapat memunculkan peluang usaha yang menjanjikan

Kata kunci : Ekonomi Kreatif, Pengabdian KepalaMasyarakat, dan Strategi Pemasaran Digital
\end{abstract}

\section{ABSTRACT}

Creative economy entrepreneur in Ragas Masigit Village, Kec. Carenang Kab. Serang is experiencing problems with digital marketing knowledge during the Covid-19 Pandemic towards society 5.0. There needs to be motivation and education that can help creative economy business actors, especially to bounce back from the uncertainty of current conditions. The purpose of this activity is to increase the synergy of community service and explain digital marketing strategies in the era of society 5.0. The types of research used in this research are surveys and case studies with descriptive methods, namely lectures, discussions and mentoring. The material presented at this community service is the pattern of digital marketing strategies in developing the creative economy during the covid 19 pandemic. The result of this activity is that participants can implement comprehensive knowledge of digital marketing strategies and products that are in demand and needed at this time that can create business opportunities. promising

Keywords: Creative Economy, Community Service, and Digital Marketing Strategy

\section{PENDAHULUAN}

Perubahan sosial adalah sebuah keniscayaan. Perkembangan sosial bergeser dari satu era ke era berikutnya dibarengi dengan perkembangan teknologi. Jepang adalah negara pertama yang secara resmi meluncurkan "society 5.0" untuk menjawab tantangan perkembangan teknologi dan problem humanistic. Konsep masyarakat yang dibangun berpusat pada manusia (human centered) dan berbasis teknologi. Konsep ini berjalan beriringan antara revolusi industry 4.0 dan society era 5.0 dimana peranan manusia akan lebih besar dengan berupaya mengoptimalkan perkembangan teknologi untuk menciptakan ruang kemanusiaan yang lebih 
Prosiding The 1st National Conference on Applied Business, Education, \& Technology (NCABET)"

Unversitas Bina Bangsa 2021

DOI Article : 10.46306/ncabet.v1i1.46

bermakna. Masyarakat Indonesia harus menyambut era ini dengan optimisme yang tinggi karena disaat negara lain sedang bermasalah dengan populasi maka negara kita justru sedang mengalami bonus demografi dimana jumlah populasi produktif lebih besar dari total keseluruhan populasi.

Berbahagialah sebagai bangsa Indonesia yang memiliki kekayaan alam yang berlimpah, Allah SWT menyediakan berbagai sumber daya alam di antaranya adalah tanah, hutan, bahan galian, ikan di laut dan ikan yang berada di perairan lainnya. Sejak zaman dulu kekayaan alam itu telah ada dan dimanfaatkan oleh manusia. Pada zaman dulu penduduk Negara kita masih sedikit cara mereka menggarap sumber daya alampun masih sederhana. Adapun sumber daya alam akan bermanfaat bagi kita jika sudah diusahakan, digali dan diolah sesuai dengan kebutuhan, jika sumber daya alam itu telah diusahakan dan dimanfaatkan berarti sumber daya alam itu telah berproduksi. Artinya dapat menghasilkan atau telah mengeluarkan hasil. (Harrys Pratama Teguh dan AR. Chaerudin, 2013).

Sekarang perubahan sosial (change of social) merupakan salah satunya dampak globalisasi serta perkembangan ilmu pengetahuan dan teknologi yang luar biasa memang telah membuat dunia serba terbuka. Ketika terjadi peningkatan aktivitas lintas-batas dan komunikasi secara maya (virtual) ke seluruh penjuru dunia dalam waktu singkat serta majunya teknologi dan komunikasi, maka hanya yang siap yang bisa meraih kesempatan. Globalisasi akan memicu perubahan tatanan pemenuhan kebutuhan secara mendasar sesuai dengan karakteristiknya yang mobile, plural, kompetitif. (Hamdan, 2011).

Tentunya, strategi dan implementasi yang tepat dalam merespon tantangan menjadi penting di sini. Kunci untuk mencapai kemajuan sudah sangat jelas, yakni penguasaan ilmu pengetahuan dan teknologi. Sejarah telah menunjukkan bahwa bangsa-bangsa yang semula miskin dan tidak diperhitungkan lagi kini menjadi bangsa yang maju karena selama puluhan tahun konsisten menginvestasikan sumber-sumber yang mereka miliki untuk mencerdaskan warganya melalui pendidikan dan dengan tekun mengejar ketertinggalan dalam ilmu teknologi.

Adapun akademisi harus terus berupaya menjawab tantangan era ini dengan konsisten melakukan riset dan pengabdian kepada masyarakat. Mendekatkan masyarakat dengan hasil riset merupakan implementasi karya yang paling bermanfaat. Temuan riset dan implementasinya dalam pengabdian menjad titik awal perkenalan masyarakat dengan teknologi tanpa kehilangan substansi kemanusiaan. Era dapat berganti, teknologi boleh berkembang lebih modern dan memudahkan tetapi esensi kemanusiaan wajib hadir dalam setiap elemen kehidupan. Semangat mengabdi kepada bangsa tercermin dalam setiap inovasi dan pemikiran 
Prosiding The 1st National Conference on Applied Business, Education, \& Technology (NCABET)"

Unversitas Bina Bangsa 2021

DOI Article : 10.46306/ncabet.v1i1.46

yang dituangkan, pergulatan teknologi dan kemanusiaan dihimpun secara apik dalam menjawab problematika sosial masyarakat.

Sejarah telah membuktikan bahwa sumber daya alam yang berlimpah ruah tanpa ditunjang oleh kemampuan menguasai teknologi tidak lagi dapat dijadikan andalan bagi suatu bangsa dalam melaksanakan pembangunan nasionalnya. Bahkan sebaliknya suatu Negara yang sama sekali tidak memiliki sumber daya alam pun, bila mampu menguasai teknologi akan dapat membangun perekonomiannya. Hal ini menunjukkan bahwa kedudukan teknologi menjadi semakin penting dan strategis serta sangat menentukan bagi daya saing suatu bangsa. Oleh karena itu seluruh Negara di dunia baik Negara indsutri maju maupun Negara berkembang saling berpacu dalam menguasai dan mengembangkan teknologi. (Bambang DS, 2011).

Teknologi adalah alat pendukung dalam melaksanakan kewajiban dan tugas, ke arah kehidupan manusia yang semakin baik dan sejahtera. Dengan bantuan teknologi, pengelola agroindustry cenderung mempunyai banyak pilihan dalam mengembangkan agroindustrinya. Pengelolaan teknologi merupakan suatu seni dan praktik dari manajemen teknologi yang fundamental. Pengelolaan teknologi mengaitkan bidang-bidang rekayasa, ilmu pengetahuan alam, dan manajemen untuk merencanakan, mengembangkan dan menerapkan kemampuankemampuan teknologi dalam membentuk dan melaksanakan tujuan-tujuan strategik dan operasional dari suatu agroindustry. (Dwi Susilowati dan Ir. Sugiarto, 2019).

Dalam permasalahan ini, sebagai akademisi baik dari Dosen atau Mahasiswa harus terus berjuang berkarya untuk Bangsa, terutama untuk meningkatkan sinergisitas pengabdian kepada masyarakat terutama dalam artikel ini yaitu pengabdian kepada masyarakat Desa Ragas Masigit Kec. Carenang Kab. Serang Prov. Banten yang banyak memilik ekonomi kreatif dan kemudian juga untuk terus melaksanakan edukasi strategi pemasaran digital. Kenapa ada keharusan seperti itu ? Karena saat ini era society 5.0 yang menghasilkan banyak transformasi dan dispursi digital. Hal ini merupakan suatu peluang, namun juga sebagai ancaman bagi sumber daya manusia khususnya generasi milenial. Saat ini pula telah terjadi pergeseran tren ekonomi, dari berbasis industry menjadi berbasis teknologi digital.

Desa Ragasmasigit Kecamatan Carenang Kabupaten Serang merupakan salah satu Desa yang ada di Indonesia harus memprioritaskan terlaksananya ekonomi kreatif desa, demi membantu masyarakatnya dalam memenuhi kebutuhan ekonomi dan membantu kemandirian dalam berusaha. Adapun mata pencarian masyarakat di Desa Ragasmasigit ini adalah sebagian besar dari hasil pertanian. Kondisi masyarakat di Desa Ragasmasigit tentram dan damai. Ini terlihat dari banyaknya fasilitas dan prasarana yang menunjang kegiatan masyarakat seperti balai desa, masjid, yayasan dan lain sebagainya. Dari segi pekerjaan sendiri mayoritas warga 
Prosiding The 1st National Conference on Applied Business, Education, \& Technology (NCABET)"

Unversitas Bina Bangsa 2021

DOI Article : 10.46306/ncabet.v1i1.46

Desa Ragasmasigit terjun pada aspek pertanian namun ada pula masyarakat karyawan memiliki usaha mandiri di rumah seperti warung kelontong, ternak bebek, ternak kambing dan masih banyak lainya.

\section{METODE PENELITIAN}

Jenis penelitian yang digunakan dalam penelitian ini adalah survey dan studi kasus dengan metode deskriptif yaitu dengan ceramah, diskusi dan pendampingan. Selanjutnya kegiatan ini dilaksanakan mengikuti lamanya masa KKM (Kuliah Kerja Mahasiswa) Kampus yaitu tiga bulan yang dimulai dari tanggal 14 Juli sampai dengan 25 September 2021. Kegiatan yang meliputi survey, persiapan, pengumpulan data, menganalisis data, dan penyusunan laporan. Waktudan kegiatan ini bersifat fleksibel. Tempat (Objek) pada penelitian ini yaitu limbah padi diolah menjadi sekam bakar padi yang terletak di Desa Ragasmasigit, Kecamatan Carenang Kabupaten Serang.

Jenis Pengumpulan data yang digunakan dalam penelitian ini adalah Data Subyek. Untuk Sumber Data yang digunakan adalah Data primer dan Data Sekunder

a Data Primer

Sumber Data Primer diperoleh melalui wawancara dengan para informan. Informan adalah orang yang dimintai keterangan tentang suatu fakta atau pendapat melalui Tanya jawab/ wawancara. Informan dalam penelitian ini adalah kelompok usaha sekam bakar padi. Dalam penelitian ini Data Primer yang digunakan adalah observasi dan wawancara langsung dengan para informan selama di lapangan.

b. Data Sekunder

Data Sekunder didapat dari objek mengenai sejarah, profil, peraturan dan kebijakan, serta dokumentasi kegiatan- kegiatan yang berkaitan dengan tempat usaha ekonomi kreatif di Desa Ragasmasigit, Kecamatan Carenang Kabupaten Serang

Teknik Pengumpulan Data Studi Lapangan, Penelitian lapangan merupakan teknik pengumpulan data dan informasi dengan cara mengadakan peninjauan dan penelitian langung di lapangan.

a Observasi

Observasi dilakukan agar mendapatkan informasi di lapangan yang berkaitan denganpelaku usaha mikro dalam memproduksi limbah padi menjadi sekam bakar padi, peneliti menggunakan teknik observasi secara langsung. Dalam hal ini peneliti terjun ke lapangan mencari berbagaiinformasi yang dibutuhkan, sehingga 
Prosiding The 1st National Conference on Applied Business, Education, \& Technology (NCABET)"

Unversitas Bina Bangsa 2021

DOI Article : 10.46306/ncabet.v1i1.46

penelitian ini bersifat rill atau fakta dan sesuai dengan apa yang terjadi dilapangan.

b. Wawancara

Wawancara digunakan sebagai media dalam mengumpulkan data agar dapat menggali atau memperoleh informasi untuk memenuhi kebutuan penelitian, antara lain mengenai bagaimana sumber daya manusia yang dilakukan oleh kelompok usaha sekam bakar padi, peneliti langsung mencari informan yang menurutnya berkaitandengan apa yang dibutuhkan dalam produksi limbah padi diolah menjadi sekam bakar padi, wawancara dilakukan dengan cara terstruktur dan terukur.

c. Dokumentasi

Dokumentasi dilakukan dengan cara memotret keadaan dan proses yang sedang dilakukan di kelompok usaha sekam bakar padi sebagai bukti nyata bahwa peneliti benar-benar meneliti tempat tersebut. Dokumentasi dapat digunakan sebagai bahan acuan dan data awal dalam melakukan wawancara dengan melakukan penelusuran tentang kegiatan yang terjadi dalam data yang ada melalui observasi dan wawancara, sekaligus dapat dijadikan sebagai bahan pendamping dari informasi yang telah diperoleh sebelumnyamelalui observasi dan wawancara.

d. Studi kepustakaan adalah kegiatan untuk menghimpun informasi yang relevan dengan topik atau masalah yang menjadi obyek penelitian. Informasi tersebut dapat diperoleh dari buku-buku, karya ilmiah, internet, dan sumber- sumber lain.
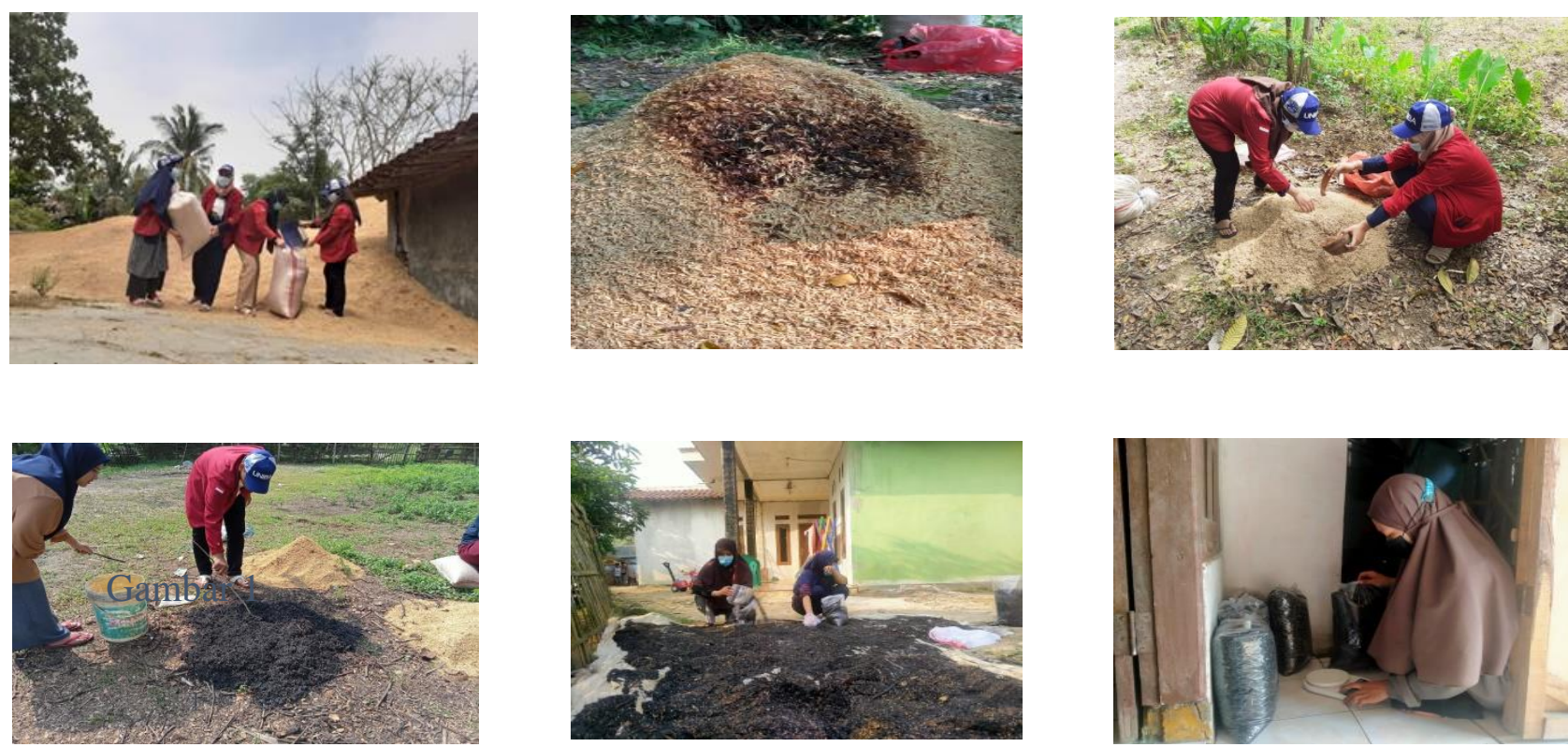

Gambar 1. Foto Proses Pembuatan Sekam Bakar Padi Sebagai Ekonomi Kreatif 
Proses pembuatan diawali dengan mengambil kulit gabah di pengilingan padi. Selanjutnya kulit gabah dituangkan di tanah menyerupai gunung dan diberi kawah untuk menaruh batok dan sabut kelapa setelah itu nyalakan api dan tunggu batok dan sabut kelapa menjadi arang setelah menjadi arang lalu tutup arang dengan kulit gabah . Tunggu sampai kulit gabah menghitam sekitar 4-5 jam. Setelah menghitam siram dengan air ,agar arang di dalamnya mati. Selanjutnya jemur sekam di bawah terik matahari agar kering dan setelah kering di kemas dan siap di jual.

Selain itu promosi yang dilakukan lewat instragam melalui media sosial bertujuan agar produk sekam bakar ini berjalan dengan lancar dan dikenal lebih luas lagi. Lewat media sosial kita juga tidak hanya mempromosi tatapi juga memberi edukasi pada konsumen
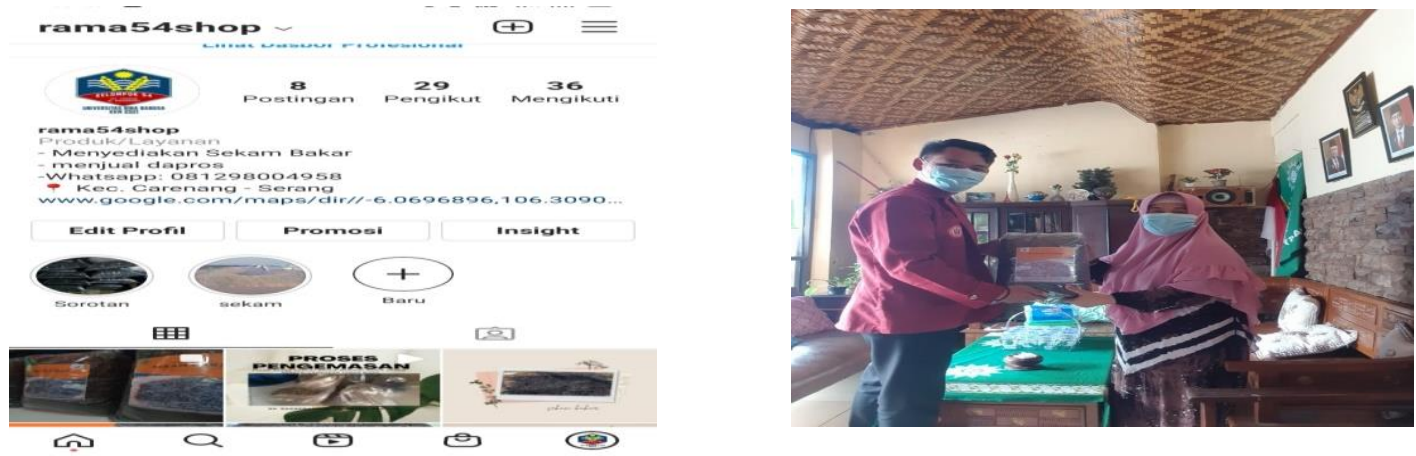

Gambar 2. Foto Media Promosi dan Penjualan Produk PKM
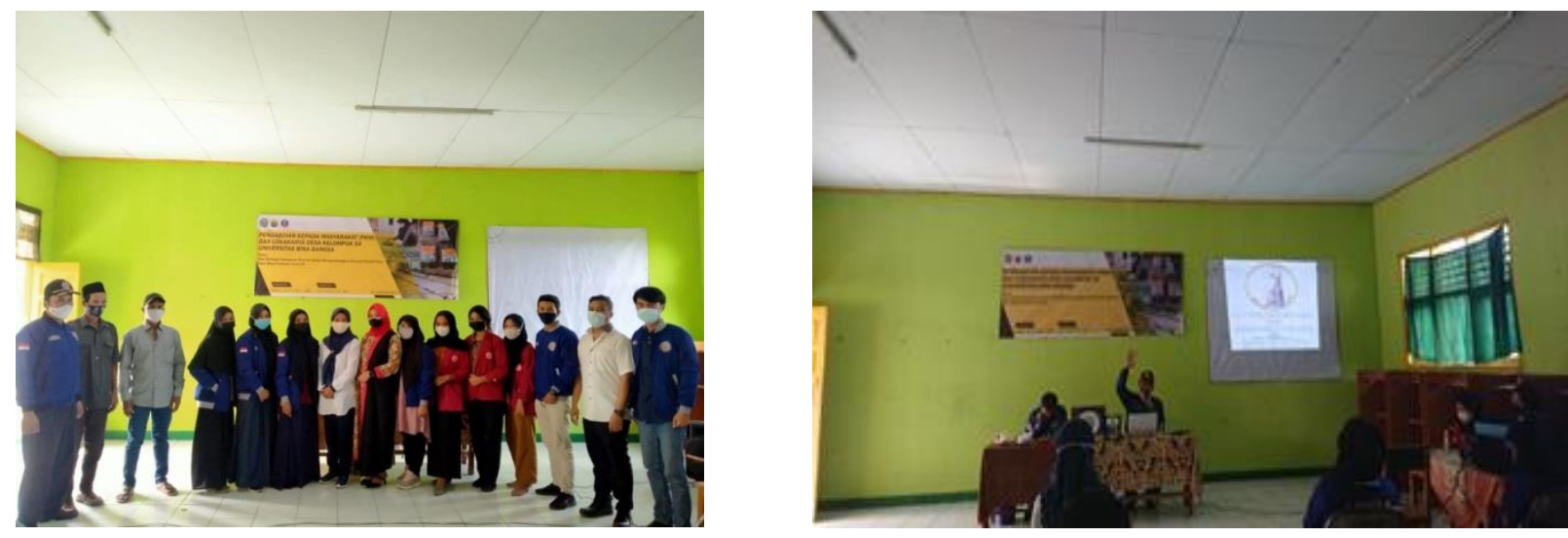

Gambar 3. Foto Proses Seminar Lokal Tentang Pola Strategi Pemasaran Digital

Beberapa langkah menuju pemberdayaaan masyarakat terutama dalam manajemen pemasaran adalah: (1) Menyiapakan produk yang akan ditampilkan di media sosial (2) menentukan target dan jenis media sosial yang digunakan sebagai sarana pemasaran. (Syaeful Bakhri, 2020). 
Prosiding The 1st National Conference on Applied Business, Education, \& Technology (NCABET)"

Unversitas Bina Bangsa 2021

DOI Article : 10.46306/ncabet.v1i1.46

Disebutkan pula bahwa konsep digital marketing 'pemasaran digital' adalah strategi atau trobosan baru untuk menembus pasar bebas sehinggga produk UMKM di indonesia dapat secara aktif terlibat memasarkan produknya bukan di dalam negeri tetapi juga dilakukan keluar negeri. Selain itu dengan pemanfaatan media sosial, pelaku UMKM dapat keuntunngan lebih, mereka juga mendapat melakukan hubungan intrens karena sebagian masyarakat cenderung menghabiskan waktu di media sosial, sehingga pelaku UMKM dapat memperoleh capaian target dan sekaligus dapat sehingga dapat meningkatkan ekonomi di tengah pandemi covid-19. (Dedi Purwana, dkk, 2017).

Lebih tegasnya, berdasarkan hasil survei, diketahui bahwa masyarakat Desa Ragas Masigit, Kecamatan Carenang Kabupaten Serang mengalami kesulitan terkait dengan strategi pemasaran digital untuk usaha ekonomi kreatif pada saat pandemi berlangsung, sehingga membuat motivasi berwirausaha menjadi padam. Oleh karenanya diperlukan adanya pemaparan materi strategi pemasaran digital dan motivasi semangat meningkatkan ekonomi kreatif di masa pandemi.

Walaupun kondisi diberlakukannya PPKM (Pemberlakuan Pembatasan Kegiatan Masyarakat) saat itu oleh pemerintah pusat, pemberian materi tetap dilaksanakan secara langsung tatap muka dengan selalu menjaga aturan protokol kesehatan sesuai intruksi Pemerintah. Dengan demikian disimpulkan bahwa metode yang dilakukan dalam pengabdian masyarakat ini ditunjukkan pada warga masyarakat Desa Ragas Masigit, Kecamatan Carenang Kabupaten Serang dilaksanakan secara langsung tatap muka dengan selalu menjaga aturan protokol kesehatan pada hari Sabtu tanggal 28 Agustus 2021 pk 13.00 WIB-16.00 WIB. Pada tahapan selanjutnya diberikan sesi tanya jawab untuk memastikan penyampaian materi sudah didapatkan dengan tepat. Adapun feedback dari masyarakat dapat diterima dengan baik

\section{HASIL DAN PEMBAHASAN}

Seminar Lokal dilaksanakan pada hari hari Sabtu tanggal 28 Agustus 2021 Jam 13.00 WIB-16.00 WIB dengan mengambil tema "1.Pola Strategi Pemasaran Digital Dalam Mengembangkan Ekonomi Kreatif Pada Masa Pandemi Covid 19”. Sesi pertama diawali dengan pembukaan oleh ketua kelompok 54 KKM UNIBA dalamprogram KKM Tematik, yaitu Saudara Muhadi. Dilanjutkan dengan pemaparan materi tentang "Pola Strategi Pemasaran Digital Dalam Mengembangkan Ekonomi Kreatif Pada Masa Pandemi Covid 19” oleh Bpk. Abdul Aziz, S.Pd.I, MM., yang merupakan dosen Manajemen di FEB Universitas Bina Bangsa (UNIBA) Serang. Seminar Lokal diakhiri dengan sesi tanya jawab yang dimoderatori oleh anggota kelompk KKM 54, Saudari Indah Pratiwi Dan Lenna Sinaga. 
Prosiding The 1st National Conference on Applied Business, Education, \& Technology (NCABET)"

Unversitas Bina Bangsa 2021

DOI Article : 10.46306/ncabet.v1i1.46

Pada saat Seminar Lokal berlangsung, peserta yang berjumlah 20 orang terlihat antusias dan mengikuti acara sampai dengan selesai. Berdasarkan hasil survei sebelum Seminar Lokal dilaksanakan, diketahui bahwa masyarakat Desa Ragas Masigit, Kecamatan Carenang Kabupaten Serang mengalami hambatan manajemen pemasaran digital pada usaha ekonomi kreatifnya. Selain itu, terdapat beberapa masyarakat yang memerlukan motivasi dan contoh penerapankreativitas yang dapat dilakukan di era pandemi ini. Dalam pelaksanaan edukasi peserta cenderung lebih banyak dari Bapak-Bapak Desa Ragas Masigit, Kecamatan Carenang Kabupaten Serang. Pada akhir sesi disimpulkan bahwa para peserta tampak memahami dengan baik pemaparan yang diberikanoleh penyaji. Sesi tanya jawab berjalan dengan baik dan diakhiri dengan foto bersama.

Berdasarkan hasil dari seminar lokal diketahui bahwa masyarakat masih belum familiar dengan istilah, teknik, tahapan serta variasi dalam manajemen pemasaran digital. Digital marketing adalah adalah kegiatan promosi dan pencarian pasar melalui media digital secara online dengan memanfaatkan berbagai sarana misalnya jejaring sosial. Penggunaan pemasaran digital dalam manajemen pemasaran tentu berbeda dengan bentuk pemasaran konvesional, misal menggunakan pamflet, baliho, dan iklan di media cetak.

Karena pada situasi Pemberlakuan Pembatasan Kegaitan Masyarakat (PPKM) mobilitas masyarakat dibatasi sehingga berimbas pada ketidakefisienan penggunaan manajemen pemasaran dengan cara tradisional. Perubahan gaya hidup pada masyarakat yang bersandar pada handphone dalam sarana transaksi jual beli juga membuat strategi manajemen pemasaran digital menjadi penting serta mendesak untuk dipelajari para wirausaha Ekonomi Kreatif. Ditambah beberapa platform digital yang gratis serta cakupan pasar potensial yang menambah daya tarik penggunaan manajemen pemasaran dengan cara online. Seminar Lokal ini diharapkan dapat mendukung para wirausaha Ekonomi Kreatif agar dapat menggunakan platform pemasaran digital dengan lebih baik, efektif dan efisien agar dapat bisnis mereka dapat bertahan di era pandemi ini. (Haryanto, dkk, 2020).

Motivasi berwirausaha memang mengalami penurunan di masa pandemi ini karena banyaknya tantangan serta perlunya tahapan adaptasi ke gaya bisnis yang baru, tentu dengan berlandaskan teknologi. Tantangan yang muncul yaitu susahnya keluar dari kebiasaan/ "zona nyaman" setelah pandemi berlangsung. Kesuksesan berwirausaha adalah kombinasi dari kepuasan individu terhadap pencapaian ekstrinsik yaitu aset finansial maupun intrinsik yaitu kepuasan batin.

Oleh karenanya, untuk mencapai kesuksesan berwirausaha dan mengatasi tantangan kebiasaan baru diperlukan pendampingan motivasi serta menerangkan betapa pentingnya 
Prosiding The 1st National Conference on Applied Business, Education, \& Technology (NCABET)"

Unversitas Bina Bangsa 2021

DOI Article : 10.46306/ncabet.v1i1.46

kreativitas yang berpotensi menjadi pembeda produk yang dihasilkan oleh para wirausaha Ekonomi Kreatif. Seminar Lokal ini diharapkan dapat menelurkan kreativitas-kreativitas yang mudah dilakukan dan bernilai ekonomis yang dapat dijual oleh para calon-calon wirausaha Ekonomi Kreatif maupun yang sudah memiliki bisnis.

Setiap masyarakat Desa harus menjadi pribadi yang sangat kreatif dalam merencanakan aktivitas perkonomian mereka. Kreativitas masyarakat Desa tersebut akan mengerakan sektor rill perekonomian pada masa Pandemi Covid 19. Kreatifitas masyarakat Desa harapan bagi ekonomi di Indonesia pada era pandemi ini. Memasukan ide, seni dan teknologi menjadi hal yang penting di era pandemik dalam pengembangan ekonomi kreatif Desa. Pengembangan ekonomi berbasis kreatifitas masyarakat Desa dapat menciptakan lapangan kerja dan meningkatkan kesejahteraan Desa.

Dalam peningkatan dan perkembangan produktivitas ekonomi kreatif akan berdampak luas pada perbaikan kesejahteraan rakyat. Karena Ekonomi kreatif salah satu fungsinya yaitu tempat dimana banyak orang menggantungkan sumber kehidupannya. Salah satu alternatif dalam meningkatkan dan mengembangkan produktivitas ekonomi kreatif adalah dengan melakukan modernisasi sistem usaha dan perangkat kebijakannya yang sistemik, sehingga akan memberikan dampak yang lebih luas lagi dalam meningkatkan daya saing daerah. (Laila Fatikhatul ula, 2020).

\section{KESIMPULAN DAN SARAN}

Sinergitas Pengabdian Kepada Masyarakat (PKM) dan Edukasi Strategi Digital Marketing di Society 5.0 di Desa Ragas Masigit, Kecamatan Carenang Kabupaten Serang dilaksanakan dalam rangka meningkatkan keahlian beriwirausaha serta memotivasi masyarakat untuk selalu bisa hidup mandiri. Pengabdian masyarakat ini sebagai salah satu bentuk implementasi ajaran Ki Hadjar Dewantara yaitu, "Opor Bebek Mateng Saka Awake Dhewe". Filosofi tersebut merujuk pada ajarah bahwa manusia hendaknya mengupayakan hidup mandiri, bebas, dan merdeka. Aplikasi ajaran tersebut tentu termasuk mandiri dalam hal ekonomi, dengan cara berwirausaha. Namun, di masa pandemi ini perlu ada penyesuaian baru dari yang biasanya dilakukan. Salah satunya adalah dalam hal pemasaran melalui digital dan motivasi berwirausaha yang berbasi kreatifitas. Hal tersebut bertujuan agar Ekonomi Kreatif dapat lebih eksis, berdaya saing, dan produk yang dihasilkan memiliki adding value. Penulis menyarankan untuk mengedukasi lebih lanjut kaitannya dengan penggunaan teknologi dalam bisnis agar dapat lebih efisien dan efektif dalam proses manajemen produksi, manajemen SDM, manajemen keuangan, dan manajemen pemasaran 


\section{UCAPAN TERIMAKASIH}

Penulis mengucapkan banyak terima kasih sebanyak-banyaknya pada: Masyarakat Desa Ragas Masigit, Kepada Desa Ragas Masigit beserta strukturalnya, Camat Kecamatan Carenang Kabupaten Serang beserta staf-stafnya atas antusiasme dan dukungannya dalam setiap tahap pengabdian masyarakat ini; begitu juga kepada Rektor Kampus dan Kepala LP2M Universitas Bina Bangsa (UNIBA) Serang atas motivasinya dan saran yang membangun kepada penulis.

\section{DAFTAR PUSTAKA}

Bambang DS. 2011. Keunggulan Insani Menuju Daya Saing Teknologi dan Ekonomi. Banten : Dinas pendidikan Prov. Banten.

Bakhri, Syaeful. 2020. Journal of communty sevices in humanities and social sciences.jurnal loyalitas sosial.Vol 2 No.2 september 2020. Scholar.google.co.id.Diakses pada 21 agustus 2021.

Fatikhatul ula, laila. 2020. Jurnal pengabdian masyarakat bidang ekonomi. Jumat. vol.1, No.1, Desember2020 Hal. 20-22 e-ISSN:2774-6755. E-journal.unwaha.ac.id. Diakses pada 21 agustus 2021.

Hamdan. 2011. Filsafat Sains . Bandung, Pustaka Setia.

Haryanto, Taufik., Sadewi Ayu, fungki.,\&Maulida Gofiruli, Bima. R.2020. Pemanfaatan digital marketing sebgai media pemasaran global untuk meningkatkan penjualan produksi pada home industry. communty empowerment. journal.unimma.ac.id. Diakses pada 7 september 2021.

Purwana, Dedi, R Rahmi, and Shandy Aditya. "Pemanfaatan Digital Marketing Bagi Usaha Mikro, Kecil, Dan Menengah (UMKM) Di Kelurahan Malaka Sari, Duren Sawit.” Jurnal Pemberdayaan Masyarakat Madani (JPMM) 1, no. 1 (2017): 1-17.

Susilowati, Dwi dan Sugiarto. 2019. Manajemen Agribisnis Penerapan pada Komoditi Pada Organik. Malang, Inteligensia Media.

Teguh, Harrys Pratama dan AR. Chaerudin. 2013. Dinamika Persoalan Ekonomi dan Penyelesaiannya di Indonesia. Yogyakarta: Phon Cahaya. 